\title{
Replacing starch by pectin and inulin in diet of early-weaned rabbits: effect on performance, health and nutrient digestibility*
}

\author{
Z. Volek ${ }^{1,3}$, M. Marounek ${ }^{1,2}$ and V. Skřivanová ${ }^{1}$ \\ ${ }^{1}$ Research Institute of Animal Production \\ CZ-104 01 Prague 10, Czech Republic \\ ${ }_{2}^{2}$ Institute of Animal Physiology and Genetics, Czech Academy of Sciences \\ CZ-142 20 Prague 4, Czech Republic
}

(Received 15 November 2004; revised version 10 February 2005; accepted 18 March 2005)

\begin{abstract}
The aim of this study was to evaluate the effect of partial replacement of starch by pectin or pectin and inulin in a diet of early-weaned rabbits. A total of 180 (60 per group) and 18 (6 per group) rabbits, 21 days old at the beginning of the experiment, were used for growth performance and intestinal traits evaluation, respectively. Digestibility of nutrients was measured individually (9 rabbits per group) between 49-53 days of age. A control, P (pectin) and PI (pectin+inulin) diet were formulated. The control diet $(18.6 \%$ starch, $4.3 \%$ pectins $)$ was fed to rabbits of the $1^{\text {st }}$ group from weaning to slaughter at the age of 77 days. Diets P (12.5\% starch, $9.0 \%$ pectins) and PI (10.3\% starch, $9.0 \%$ pectins, supplemented with $4 \%$ inulin) were fed to rabbits of the respective group from weaning to 42 days of age, then rabbits received the control diet till slaughter. For the intestinal measurements, rabbits were slaughtered at the age of 42 days. Rabbits fed the control, $\mathrm{P}$ and PI diet gained on average 43.9, 44.6 and $45.0 \mathrm{~g} / \mathrm{d}$, respectively. For the whole fattening period, the lowest mortality was observed in rabbits fed the PI diet $(25.0,33.3$ and $43.3 \%$ in rabbits fed the PI, control and $\mathrm{P}$ diet, respectively; $\mathrm{P}=0.10)$. Total VFA concentration in the caecum of rabbits fed diet supplemented with inulin (PI diet) was significantly higher $(\mathrm{P}=0.02)$ and the $\mathrm{pH}$ lower $(\mathrm{P}<0.001)$ than in the caecum of others rabbits. The viscosity of the small intestinal contents was higher in rabbits fed $\mathrm{P}$ and $\mathrm{PI}$ diet than in control $(\mathrm{P}=0.10)$. The significantly higher digestibility of crude protein $(\mathrm{P}<0.01)$, as well as starch was observed in rabbits fed control diet than in other rabbits. It can be concluded that a partial replacement of starch by digestible fibre in a diet of earlyweaned rabbits did not improve their health. The high mortality rate, however, was decreased by supplementation of the starter diet with $4 \%$ of inulin.
\end{abstract}

KEY WORDS: rabbit, starter diet, starch, pectin, inulin

\footnotetext{
* Supported by the Czech Science Foundation, Project No. 523/03/DO11

${ }^{3}$ Corresponding author: e-mail: volek.zdenek@vuzv.cz
} 


\section{INTRODUCTION}

Early weaning around 21-25 days of age may improve the corporal condition of does and allows a specific nutrition of young rabbits around weaning time (Pascual, 2001; Xiccato et al., 2004). However, mainly from a health point of view, nutritional needs of the young rabbit require to be more fully known. One of the main problems in formulating starter diets is to find suitable sources and levels of carbohydrates. Dietary starch, which is the most important polysaccharide of concentrates, is incompletely hydrolysed in the small intestine of weanling rabbits. Consequently, the amount of starch reaching the caecum increases with increasing dietary starch concentration in the post-weaning period. The resulting carbohydrate overload increases the likelihood of digestive disorders (Cheeke and Patton, 1980). Thus, there is a need to substitute starch in part by other carbohydrates, which do not cause digestive problems. Gutiérrez et al. (2002) e.g., tested the replacement of starch by lactose. The results of their experiment, however, were not favourable because incorporation of lactose into diet for early weaned rabbits caused fall in digestibility and increased mortality. Another starch alternative in the starter diet of early-weaned rabbits can be dietary pectin and inulin. Perez et al. (2000) demonstrated a reduction of mortality in traditionally weaned rabbits (between 28 and 35 days of age) when starch was replaced by easily fermentable polysaccharides (pectins + hemicelluloses). Gidenne et al. (2002) reported a great increase of bacterial fibrolytic activity in the caecum between 21 and 28 days of age. After weaning the fibrolytic activity did not change significantly. In addition, supplying high quantity of digestible fibre promoted a high fermentative activity already at weaning, which might be favourable for health. An adequate supply of fibre, with high proportions in rapidly fermentable polysaccharides, stimulated the maturation of microbial activity and reduced the occurrence of diarrhoea (Gidenne et al., 2004a). Several papers deal with the use of fructooligosaccharides in rabbit diets (Morisse et al., 1993; Lebas, 1996; Maertens et al., 2004). Inulin is a polysaccharide composed of $\beta$-2,1-linked fructosyl moieties, containing a small amount of glucose. It is a storage carbohydrate, widespread in plants. Most of the inulin commercially available today is extracted from chicory roots. This type of inulin has a degree of polymerization of 2-60, with an average ranging from 9 to 25 (Meyer et al., 2004). Inulin and oligofructose (fructans of low molecular weight) are considered to be "prebiotics" because they are not hydrolytically digested, but are selectively fermented in the colon to support the growth of beneficial bacterial populations (Gibson and Roberfroid, 1995). Inulin and oligofructose have attracted the attention of nutritionists because of their beneficial effect on the health of the gastrointestinal tract of animals (reviewed by Flickinger et al., 2003).

Thus, the aim of this study was to evaluate the effect of a partial replacement of starch by dietary pectin or pectin and inulin in the diet of early weaned rabbits on growth, health status, intestinal traits and digestibility of nutrients. 


\section{MATERIAL AND METHODS}

\section{Animals, diets and recordings}

A total of 180 early-weaned rabbits $\left(\right.$ Hyplus $\left.^{\circledR}\right), 21$-days old at the beginning of experiment, were divided into three groups. Rabbits, born in a commercial rabbitry, were kept in all-wire cages, three per cage. Three experimental diets (Table 1) were formulated: control diet, diet P (rich in pectin) and diet PI (rich in pectin+chicory inulin). The diets were similar in the level of crude protein, NDF

TABLE 1

Ingredients of control diet, P diet (pectin) and PI diet (pectin+inulin), $\%$

\begin{tabular}{|c|c|c|c|}
\hline \multirow{2}{*}{ Ingredients, $\%$} & \multicolumn{3}{|c|}{ Diet } \\
\hline & control & $\mathrm{P}$ & PI \\
\hline Lucerne meal & 28 & 28 & 28 \\
\hline Extracted sunflower meal & 15 & 15 & 15 \\
\hline Extracted soyabean meal & 3 & 5 & 5 \\
\hline Wheat bran & 26 & 6 & 6 \\
\hline Sugar beet pulp & 0 & 20 & 20 \\
\hline Oats & 9 & 10 & 10 \\
\hline Barley & 15 & 12 & 8 \\
\hline Inulin (Frutafit $\left.{ }^{\mathbb{R}} \mathrm{IQ}\right)$ & 0 & 0 & 4 \\
\hline Molasses & 1 & 1 & 1 \\
\hline Vitamin supplement ${ }^{1}$ & 1 & 1 & 1 \\
\hline Dicalcium phosphate & 0.5 & 0.5 & 0.5 \\
\hline Limestone & 1 & 1 & 1 \\
\hline Salt & 0.5 & 0.5 & 0.5 \\
\hline
\end{tabular}

and ADF, but differed mainly in the level of starch, pectins and fructans (Table 2). The control diet contained more starch and less pectins than other diets. A higher pectin content in the P and PI diet was supplied through sugar beet pulp at the expense of wheat bran content. The PI diet was supplemented with $4 \%$ chicory inulin by means of Frutafit ${ }^{\circledR}$ IQ (SENSUS, 4704 RG Roosendaal, The Netherlands). Frutafit ${ }^{\circledR}$ IQ is the instantized version of powdered inulin. According to Meyer et al. (2004), about $85 \%$ of inulin molecules in the Frutafit ${ }^{\mathbb{B}} \mathrm{IQ}$ consist of 6 or more glycosyl residues. Apart from salinomycin, an ionophore used to control coccidiosis, the diets did not contain any commercial antimicrobials. 
TABLE 2

Chemical composition of control diet, P diet (pectin) and PI diet (pectin+inulin), g/kg

\begin{tabular}{lccc}
\hline \multirow{2}{*}{ Composition, g/kg } & \multicolumn{3}{c}{ Diet } \\
\cline { 2 - 4 } & Control & $\mathrm{P}$ & $\mathrm{PI}$ \\
\hline Organic matter & 839 & 842 & 837 \\
Crude protein & 185 & 180 & 175 \\
$\mathrm{NDF}$ & 337 & 350 & 342 \\
$\mathrm{ADF}$ & 190 & 203 & 200 \\
$\mathrm{ADL}$ & 56 & 52 & 50 \\
Hemicelluloses (NDF-ADF) & 147 & 147 & 142 \\
Cellulose (ADF-ADL) & 134 & 151 & 150 \\
NNCC & 317 & 312 & 320 \\
Pectins $^{2}$ (water insoluble) & 43 & 90 & 90 \\
Fructans $^{2}$ & 8 & 4 & 44 \\
Starch $^{\text {Ether extract }}$ & 186 & 125 & 103 \\
Digestible energy $^{2}, \mathrm{MJ} / \mathrm{kg}$ & 30 & 26 & 25 \\
\hline
\end{tabular}

${ }^{1}$ non-nitrogen cellular content $(\mathrm{NNCC})=\mathrm{OM}$ - CP - NDF

${ }^{2}$ calculated values

The control diet was fed to rabbits of the $1^{\text {st }}$ group from weaning to slaughter at 77 days of age. P and PI diets were fed to rabbits of the respective group from weaning to 42 days of age, and then rabbits received the control diet till slaughter. Diets and water were available ad libitum. Feed intake was measured weekly per group. Animals were individually weighed every week. Mortality was recorded every day; morbidity was recorded twice a week. A rabbit was considered morbid only one time. Dead animals were only considered in mortality rate. For growth performance traits evaluation, data only from healthy rabbits were used (initial number of rabbits at weaning minus morbidity and mortality) (Table 3). Dead rabbits were examined using standard pathological, bacteriological and parasitological methods in the State Veterinary Institute in Prague.

\section{Intestinal traits}

A total of 18 early-weaned rabbits (Hyplus ${ }^{\circledR}$ ), 21 days old at the beginning of the experiment, were used for the intestinal measurements. Rabbits were assigned at random to the three experimental diets (control, P and PI diet). Both feed and water were available ad libitum. Rabbits were slaughtered at the age of 42 days (on average $1.3 \mathrm{~kg}$ liveweight). After slaughtering, both small intestinal and caecal contents were squeezed out, and used for analyses. 


\section{Total tract digestibility trials}

A total of 27 early-weaned rabbits (Hyplus ${ }^{\circledR}$ ), 21 days old at the beginning of the experiment, were used for determination of the coefficient of the total tract apparent digestibility of organic matter (OM), crude protein (CP), ether extract (EE), non-nitrogenous cellular content (NNCC), starch, neutral detergent fibre (NDF) and acid detergent fibre (ADF). Rabbits were assigned at random to the three experimental diets (control, P and PI diet). Both feed and water were available ad libitum. The measurement of the total tract apparent digestibility of experimental diets was performed individually between 49 and 53 days of age, according to European reference method (Perez et al., 1995).

\section{Analytical methods and statistical analyses}

Feed samples were air-dried at $105^{\circ} \mathrm{C}$ to constant weight to estimate the dry matter content. Protein and fat concentrations were determined employing the Kjeltec Auto 1030 Analyser and Soxtec 1043 from Tecator AB (Sweden), respectively. Neutral detergent fibre (NDF), acid detergent fibre (ADF) and acid detergent lignin (ADL) were determined according to the procedure of Van Soest et al. (1991), using Fibertec 2010. Water insoluble pectins and digestible energy were calculated from tables of ingredients (Maertens et al., 2002), as well as fructans (Knudsen, 1997). The non-nitrogenous cellular content (NNCC), which includes starch and also the major part of pectins, was estimated by difference according to the relation: NNCC=OM-CP-NDF (Gidenne et al., 2004b). Starch was measured polarimetrically (Ewers procedure). Volatile fatty acids (VFA) in the caecal contents were determined in diluted samples by titration, after steam distillation. Viscosity was determined in the whole digesta of the small intestine of rabbits using Visco Tester VT6L, equipped with a small samples adapter (ThermoHaake, Karlruhe, Germany). Viscosity was expressed in $\mathrm{mPa} \cdot \mathrm{s}$.

The statistical analysis of the data was performed by one-way analysis of variance by the GLM procedure of SAS (SAS Institute Inc., Cary, NC). Sheffe test was used for mean comparison where appropriate. Data on mortality and morbidity were analysed using the $\chi^{2}$ test. The statistical significance was declared at $\mathrm{P}<0.05$.

\section{RESULTS}

Diets, rabbit growth and health status. In accordance with the objectives of the experiment, the three experimental diets were similar in their levels of NDF, ADF and CP, but differed in the level of starch (Table 2). Starch was partially replaced by dietary pectin or dietary pectin and chicory inulin in the P and PI diet, respectively. 
There were no significant differences among groups in the performance traits (Table 3). Rabbits fed the control, P and PI diet gained on average 43.9, 44.6 and $45.0 \mathrm{~g} / \mathrm{d}$, respectively $(\mathrm{P}>0.05)$. Corresponding feed consumption per $\mathrm{kg}$ of gain was $3.84,3.57$ and $3.23 \mathrm{~kg}$.

TABLE 3

Performance traits of rabbits fed control, P (pectin) and PI diet (pectin+inulin)

\begin{tabular}{|c|c|c|c|c|c|}
\hline & \multicolumn{3}{|c|}{ Diet } & \multirow{2}{*}{ R.M.S.E ${ }^{1}$} & \multirow{2}{*}{ P-level } \\
\hline & control & $\mathrm{P}$ & PI & & \\
\hline Rabbits, $n^{2}$ & 33 & 26 & 35 & & \\
\hline \multicolumn{6}{|l|}{ Liveweight, $g$} \\
\hline after weaning, $21 \mathrm{~d}$ & 481 & 487 & 484 & 19.3 & NS \\
\hline before slaughter, $77 \mathrm{~d}$ & 2942 & 2986 & 3006 & 306.4 & NS \\
\hline \multicolumn{6}{|l|}{ Weight gain, g/d } \\
\hline $21-42$ day of age & 40.0 & 41.9 & 42.3 & 9.6 & NS \\
\hline 43-77 day of age & 46.3 & 46.2 & 46.6 & 6.7 & NS \\
\hline whole period & 43.9 & 44.6 & 45.0 & 5.5 & NS \\
\hline \multicolumn{6}{|l|}{ Feed conversion, $\mathrm{kg} / \mathrm{kg}$} \\
\hline $21-42$ day of age & 2.48 & 1.94 & 1.68 & - & - \\
\hline whole period & 3.84 & 3.57 & 3.23 & - & - \\
\hline
\end{tabular}

${ }^{1}$ root mean square error

${ }^{2} \mathrm{n}=$ initial number of rabbits at weaning (60 per group) minus morbidity and mortality NS - not significant

As far as the health status of rabbits is concerned, neither mortality nor morbidity were significantly affected by dietary treatments in the first three weeks after weaning (Table 4). However, for the whole fattening period, the lowest mortality was observed in rabbits fed diet supplemented with inulin (25.0, 33.3 , and $43.3 \%$ in rabbits fed the PI, control and $\mathrm{P}$ diet, respectively; $\mathrm{P}=0.10$ ).

TABLE 4

Mortality $^{1}$ and morbidity ${ }^{1}$ of rabbits $^{2}$ fed control, P (pectin) and PI diet (pectin + inulin)

\begin{tabular}{ccccc}
\hline & \multicolumn{3}{c}{ Diet } & \multirow{2}{*}{ P-level } \\
\cline { 2 - 4 } & control & P & PI & \\
Mortality, \% (n) & & & & \\
21-42 days of age & $31.7(19)$ & $36.6(22)$ & $23.3(14)$ & NS \\
21-77 days of age & $33.3(20)$ & $43.3(26)$ & $25.0(15)$ & 0.10 \\
Morbidity, \% (n) & & & & \\
21-42 days of age & $8.3(5)$ & $10.0(6)$ & $8.3(5)$ & NS \\
21-77 days of age & $11.6(7)$ & $13.3(8)$ & $16.6(10)$ & NS \\
\hline
\end{tabular}

${ }^{1}$ numbers of dead and ill rabbits are given in parentheses

${ }^{2} 60$ rabbits per group at the beginning of the trial 
Intestinal traits and digestibility of the experimental diets. Table 5 presents total caecal concentrations of volatile fatty acids (VFA), caecal $\mathrm{pH}$, and viscosity of the small intestinal content of rabbits fed diets with different level of starch, pectins and fructans, and slaughtered at 42 days of age.

TABLE 5

Total caecal concentrations of volatile fatty acids (VFA), $\mathrm{pH}$, and intestinal viscosity of rabbits fed control, P (pectin) and PI diet (pectin+inulin) at 42 days of age

\begin{tabular}{|c|c|c|c|c|c|}
\hline & \multicolumn{3}{|c|}{ Diet } & \multirow{2}{*}{ R.M.S.E. ${ }^{1}$} & \multirow{2}{*}{ P-level } \\
\hline & control & $\mathrm{P}$ & PI & & \\
\hline \multicolumn{6}{|l|}{ Small intestine } \\
\hline viscosity, $\mathrm{mPa} \cdot \mathrm{s}$ & 492 & 2240 & 1812 & 1118.2 & 0.10 \\
\hline \multicolumn{6}{|l|}{ Caecum } \\
\hline total VFA, $\mathrm{mmol} / \mathrm{L}$ & $77.2^{\mathrm{ab}}$ & $60.0^{\mathrm{a}}$ & $93.4^{b}$ & 16.2 & 0.02 \\
\hline $\mathrm{pH}$ & $5.9^{\mathrm{a}}$ & $6.2^{\mathrm{a}}$ & $5.6^{\mathrm{b}}$ & 0.2 & $<0.001$ \\
\hline
\end{tabular}

Concentrations of VFA in the caecal contents were significantly higher $(\mathrm{P}=0.02)$ and the $\mathrm{pH}$ significantly lower $(\mathrm{P}<0.001)$ in rabbits fed diet supplemented with inulin (PI diet) than in the others rabbits. The viscosity of the small intestinal content was higher in rabbits fed $\mathrm{P}$ and $\mathrm{PI}$ diet than in control rabbits $(\mathrm{P}=0.10)$.

There were some differences in digestibility of crude protein, starch and non-nitrogenous cellular content in rabbits fed experimental diets (Table 6). Digestibility of crude protein was significantly lower $(\mathrm{P}<0.01)$, as well as that of non-nitrogenous cellular content $(\mathrm{P}=0.01)$ in rabbits fed $\mathrm{P}$ and $\mathrm{PI}$ diet than in

TABLE 6

Total tract apparent digestibility (TTAD) of control, P (pectin) and PI diet (pectin+inulin)

\begin{tabular}{lccccc}
\hline \multirow{2}{*}{ TTAD coefficients, \% } & \multicolumn{3}{c}{ Diet } & \multirow{2}{*}{ R.M.S.E. ${ }^{1}$} & P-level \\
\cline { 2 - 4 } & control & $\mathrm{P}$ & PI & & \\
\hline Organic matter & 73.9 & 70.1 & 69.0 & 4.8 & $\mathrm{NS}$ \\
Crude protein $(\mathrm{N} \times 6.25)$ & $79.5^{\mathrm{a}}$ & $72.9^{\mathrm{b}}$ & $71.0^{\mathrm{b}}$ & 3.7 & $<0.01$ \\
Ether extract & 90.6 & 88.6 & 89.1 & 1.8 & $\mathrm{NS}$ \\
NNCC $^{2}$ & $95.8^{\mathrm{a}}$ & $93.4^{\mathrm{b}}$ & $93.6^{\mathrm{b}}$ & 1.5 & 0.01 \\
Starch $_{\text {NDF }}$ & $97.5^{\mathrm{a}}$ & $96.7^{\mathrm{a}}$ & $95.3^{\mathrm{b}}$ & 0.6 & $<0.001$ \\
ADF & 46.4 & 47.9 & 46.7 & 8.0 & $\mathrm{NS}$ \\
\hline
\end{tabular}

${ }^{1}$ root mean square error

${ }^{2}$ non-nitrogenous cellular content $(\mathrm{NNCC})=\mathrm{OM}-\mathrm{CP}-\mathrm{NDF}$

${ }^{\mathrm{ab}}$ values in the same row with unlike superscript differ significantly $(\mathrm{P}<0.05)$

NS-not significant 
those fed control diet. In rabbits fed the diet supplemented with inulin (PI diet) also significantly lower digestibility of starch was found. There were no significant differences in digestibility of fibre fractions (NDF and ADF).

\section{DISCUSSION}

In the present study, we observed differences among groups in the viscosity of the small intestinal content, as well as in total caecal concentrations of volatile fatty acid (VFA) and caecal pH (Table 5). The higher viscosity of the small intestinal content was found in rabbits fed diets with a high level of dietary pectins (P and PI diet) than in those fed control diet. Significantly higher total caecal concentrations of VFA and significantly lower $\mathrm{pH}$ were observed in rabbits fed diet supplemented with inulin. This is in agreement with Morisse et al.(1993) who reported a lower $\mathrm{pH}$, a strong rise in total VFA and marked decrease of caecal ammonia when rabbits received diet supplemented with fructooligosaccharides (FOS). Similarly, Maertens et al. (2004) showed a tendency to reduced $\mathrm{pH}$ in the caecum of inulinfed rabbits. Zdunczyk et al. (2004) observed a significant drop of $\mathrm{pH}$ in the caecal digesta of rats fed a diet supplemented with inulin and lactulose.

No differences were observed in fibre digestion in this study (Table 6). Similarly, Gidenne et al. (2004b) showed that fibre digestion was not affected when starch replaced rapidly fermentable polysaccharides. Gidenne et al. (2004a) also observed no significant differences in the fibre digestive efficiency in rabbits fed diets with varying fibre:starch ratio. The significantly higher digestibility of starch, as well as that of non-nitrogenous cellular content in rabbits fed diet with the highest level of starch is in agreement with other studies (Gidenne and Perez, 2000; Gidenne et al., 2004b).

There are indications in the literature that digestibility of protein in rabbits fed diets rich in easily fermentable polysaccharides (mainly pectins) is lower than in rabbits fed diets containing lower concentrations of fermentable polysaccharides (Garcia et al., 1993; Gidenne et al., 2004a,b). This has been shown also in our study. In our opinion, this may be associated with the higher viscosity of digesta within the small intestine of rabbits fed diets with the high level of pectins ( $\mathrm{P}$ and PI diet).

There were no significant differences among rabbits fed diets with different level of starch, pectins and fructans with regard to weight gain, although a slightly better growth rate were observed in rabbits fed the diet with inulin (Table 3). Similarly, during the whole fattening period, Perez et al. (2000) observed no significant differences in the weight gain of rabbits when starch replaced rapidly fermentable polysaccharides. 
In the present study, replacing starch by dietary pectin in the diet of earlyweaned rabbits did not improve the health status of rabbits in the first three weeks after weaning. This is in agreement with Gidenne et al. (2004b) who reported that digestive health of the growing rabbits was not improved when digestible fibre (with a high proportion of pectins) replaced starch, but contrary to studies of Jehl and Gidenne (1996), Perez et al. (2000) and Gidenne et al. (2004a). In our study, the average high mortality rate was due to mixed bacterial infection (mainly Escherichia coli and Clostridium perfringens). Most of the rabbits died between 30 and 42 days of age. Similarly, Gidenne and Fortun-Lamothe (2001) reported that early-weaned rabbits (23 days) were more susceptible to a colibacillosis after weaning. As shown above, the diets in which starch was partially replaced by dietary pectins (P and PI diet) increased viscosity of digesta within the small intestine (Table 5). This may be the reason of increased mortality of rabbits fed the diet $\mathrm{P}$, as in piglets weaned at $21 \mathrm{~d}$ of age the increase of viscosity of the intestinal contents encouraged proliferation of haemolytic E. coli in the small intestine and colonization of Brachyspira pilosicoli in the large intestine (Hopwood et al., 2002). The addition of inulin into PI diet had a positive effect on mortality (Table 4). It was probably associated with prebiotic activity of inulin because significantly higher total caecal concentrations of VFA, as well as significantly lower caecal $\mathrm{pH}$ in rabbits fed diet supplemented with inulin were found (Table 5). After starter period (21-42 days of age), a slightly higher mortality and morbidity were observed in rabbits fed the P and PI diet, respectively, than in rabbits fed control diet. This might be caused by the change of diet. Similarly, Gutiérrez et al. (2002) observed increased incidence of mortality during the week following the change from the starter diet to the fattening feed.

\section{CONCLUSIONS}

It can be concluded that $(i)$ the growth of rabbits was not significantly affected by dietary pectin and chicory inulin, (ii) the partial replacement of starch by dietary pectin in the starter diet did not improve the health of rabbits, (iii) diets with high pectin concentrations increased viscosity of the small intestinal content and decreased digestibility of crude protein, non-nitrogen cellular content and starch, (iv) the addition of inulin positively affected some physiological variables of the caecum of rabbits (total VFA and $\mathrm{pH}$ ) and decreased mortality of rabbits. 


\section{REFERENCES}

Cheeke P.R., Patton N.M., 1980. Carbohydrate-overload of the hindgut. A probable cause of enteritis. J. Appl. Rabbit Res. 3, 20-23

Flickinger E.A., Van Loo J., Fahey G.C., 2003. Nutritional responses to the presence of inulin and oligofructose in the diets of domesticated animals. A review. Crit. Rev. Food Sci. Nutr. 43, 19-60

Garcia G., Galvez J.F., De Blas J.C., 1993. Effect of substitution of sugar-beet pulp for barley in diets for finishing rabbits on growth performance and on energy and nitrogen efficiency. J. Anim. Sci. 71, 1823-1830

Gibson G.R., Roberfroid M.B., 1995. Dietary modulation of the human colonic microbiota: introducing the concept of prebiotics. J. Nutr. 125, 1401-1412

Gidenne T., Fortun-Lamothe L., 2001. Early weaning: effect on performance and health. Proceedings of the $2^{\text {nd }}$ Meeting of WG 3 and WG 4. COST Action 848. Gödöllö (Hungary), p. 44

Gidenne T., Jehl N., Lapanouse A., Segura M., 2004a. Inter-relationship of microbial activity, digestion and gut health in the rabbit: effect of substituting fibre by starch in diets having a high proportion of rapidly fermentable polysaccharides. Brit. J. Nutr. 92, 95-104

Gidenne T., Jehl N., Segura M., Michalet-Doreau B., 2002. Microbial activity in the caecum of the rabbit around weaning: impact of a dietary fibre deficiency and of intake level. Anim. Feed Sci. Tech. 99, 107-118

Gidenne T., Mirabito L., Jehl N., Perez J.M., Arveux P., Bourdillon A., Briens C., Duperray J., Corrent E., 2004b. Impact of replacing starch by digestible fibre, at two levels of lignocellulose, on digestion, growth and digestive health of the rabbit. Anim. Sci. 78, 389-398

Gidenne T., Perez J.M., 2000. Replacement of digestible fibre by starch in the diet of the growing rabbit. I. Effects on digestion, rate of passage and retention of nutrients. Ann. Zootech. 49, 357-368

Gutiérrez I., Espinosa A., García J., Carabaño R., de Blas J.C., 2002. Effect of levels of starch, fiber, and lactose on digestion and growth performance of early-weaned rabbits. J. Anim. Sci. 80, 1029-1037

Hopwood D.E., Pethick D.W., Hampson D.J., 2002. Increasing the viscosity of the intestinal contents stimulates proliferation of enterotoxigenic Escherichia coli and Brachyspira pilosicoli in weaner pigs. Brit. J. Nutr. 88, 523-532

Jehl N., Gidenne T., 1996. Replacement of starch by digestible fibre in feed for the growing rabbit. 2. Consequences for microbial activity in the caecum and on incidence of digestive disorders. Anim. Feed Sci. Tech. 61, 193-204

Knudsen K.B.E., 1997. Carbohydrate and lignin contents of plant materials used in animal feeding. Anim. Feed Sci. Tech. 67, 319-338

Lebas F., 1996. Effects of fructooligosaccharides origin on rabbits growth performance in 2 seasons. In: F. Lebas (Editor). Proceedings of the $6^{\text {th }}$ World Rabbit Congress. AFC Lempdes (France), pp. 211-215

Maertens L., Aerts J.M., De Boever J., 2004. Degradation of dietary oligofructose and inulin in the gastro-intestinal tract of the rabbit and the effects on caecal $\mathrm{pH}$ and volatile fatty acids. World Rabbit Sci. 12, 235-246

Maertens L., Perez J.M., Villamide M., Cervera C., Gidenne T., Xiccato G., 2002. Nutritive value of raw materials for rabbits: EGRAN Tables 2002. World Rabbit Sci. 10, 157-166

Meyer D., van Nuenen M., Venema K., 2004. The effect of various inulins and Clostridium difficile on the metabolic activity and composition of the human colonic microbiota in vitro. In: J.W. van der Kamp, N.-G. Asp, J. Miller Jones, G. Schaafsma (Editors). Dietary Fibre: Bio-active Carbohydrates for Food and Feed. Wageningen Academic Publishers (The Netherlands), pp. $237-253$ 
Morisse J.P., Maurice R., Boilletot E., Cotte J.P., 1993. Assessment of the activity of fructooligosaccharide on different cecal parameters in rabbits experimentally infected with Escherichia coli O.103. Ann. Zootech. 42, 81-87

Pascual J.J., 2001. Early weaning of young rabbits: A review. World Rabbit Sci. 9, 165-170

Perez J.M., Gidenne T., Bouvarel I., Arveux P., Bourdillon A., Briens C., Le Naour J., Messager B., Mirabito L., 2000. Replacement of digestible fibre by starch in the diet of the growing rabbit. II. Effects on performances and mortality by diarrhoea. Ann. Zootech. 49, 369-377

Perez J.M., Lebas F., Gidenne T., Maertens L., Xiccato G., Parigi Bini R., Dalle Zotte A., Cossu M.E., Carazzolo A., Villamide M., Carabaño R., Fraga M.J., Ramos M.A., Cervera C., Blas E., Fernández Carmona J., Falcao-e-Cunha L., Bengala Freire J., 1995. European reference method for in vivo determination of diet digestibility in rabbits. World Rabbit Sci. 3, 41-43

Van Soest P.J., Robertson J.B., Lewis B.A., 1991. Methods for dietary fiber, neutral detergent fiber, and non starch polysaccharides in relation to animal nutrition. J. Dairy Sci. 74, 3583-3597

Xiccato G., Trocino A., Sartori A., Queaque P.I., 2004. Effect of parity order and litter weaning age on the performance and body energy balance of rabbit does. Livest. Prod. Sci. 85, 239-251

Zdunczyk Z., Juskiewicz J., Wroblewska M., Krol B., 2004. Physiological effects of lactulose and inulin in the caecum of rats. Arch. Anim. Nutr. 58, 89-98

\section{STRESZCZENIE}

\section{Zastąpienie skrobi w dietach dla weześnie odłączonych królicząt pektyną i inuliną: wpływ na wzrost i rozwój, stan zdrowia oraz strawność składników pokarmowych diety}

Celem pracy było zbadanie wpływu częściowego zastapienia skrobi pektyną lub pektyną i inuliną w dietach dla wcześnie odłączonych królicząt. Sto osiemdziesiąt (po $60 \mathrm{w}$ grupie) i 18 królicząt (po $6 \mathrm{w}$ grupie), 21-dniowych na początku doświadczenia, użyto w doświadczeniu wzrostowym oraz w badaniach nad określeniem wskaźników treści jelitowej. Strawność składników pokarmowych oznaczano na 9 królikach z każdej grupy, między 40 a 53 dniem życia. Króliczęta otrzymywały następujące diety: kontrolną, P- pektynową lub PI (pektyna+inulina). Dietę kontrolną (18.6\% skrobi, $4.3 \%$ pektyny) podawano króliczętom od odsadzenia do uboju w 77 dniu życia, diety P (12\% skrobi, 9\% pektyny) i P1 (10, 3\% skrobi, 9,0\% pektyny $+4 \%$ inuliny) - od odsadzenia do 42 dnia życia, po czym otrzymywały dietę kontrolną do uboju. Oznaczenie parametrów w treści jelit wykonano po uboju zwierząt w 42 dniu życia.

Średnie przyrosty królicząt $\mathrm{w}$ grupach kontrolnej, P i PI wynosiły odpowiednio 43,9; 44,6 i 45,0 g/dzień. Najniższą śmiertelność stwierdzono w grupie PI (25,0; 33,3 i 43,3\%, odpowiednio w grupach PI, kontrolnej i $\mathrm{P} ; \mathrm{P}=0,10)$. Stężenie lotnych kwasów tłuszczowych w jelicie ślepym królicząt $\mathrm{z}$ grupy $\mathrm{PI}$ było istotnie wyższe $(\mathrm{P}=0,02)$, a $\mathrm{pH}$ niższe $(\mathrm{P}<0,001)$ niż u królicząt $\mathrm{z}$ pozostałych grup. Lepkość treści jelita cienkiego była większa u królicząt $\mathrm{z}$ obydwóch grup doświadczalnych niż w kontrolnej $(\mathrm{P}=0,01)$. Strawność białka ogólnego oraz skrobi była istotnie większa $(\mathrm{P}<0,01) \mathrm{w}$ grupie kontrolnej niż w pozostałych grupach.

W podsumowaniu można stwierdzić, że częściowe zastąpienie skrobi w dietach dla wcześnie odłączonych królicząt przez strawne włókno nie wpływa na poprawę zdrowia zwierząt. Wysoka śmiertelność może być jednak zmniejszona przez dodatek do diet $4 \%$ inuliny. 